\title{
ASSESSMENT OF EFFICIENCY OF MILITARY TRANSPORT UNITS USING THE DEA AND SFA METHODS
}

\author{
Dejan R. Despića ${ }^{a}$ Nebojša J. Bojovićb, \\ Milorad J. Kilibardac ${ }^{c}$, Marko V. Kapetanović ${ }^{d}$ \\ ${ }^{a}$ Ministry of Defence of the Republic of Serbia, \\ Material Resources Sector, Department for General Logistics, \\ Belgrade, Republic of Serbia, \\ e-mail: dejandespic79@gmail.com, \\ ORCID iD: (Dhttps://orcid.org/0000-0001-5256-3436 \\ ${ }^{b}$ University of Belgrade, Faculty for Transport and Traffic Engineering, \\ Belgrade, Republic of Serbia, \\ e-mail: nb.bojovic@sf.bg.ac.rs, \\ ORCID iD: (1)https://orcid.org/0000-0001-5600-3807 \\ c University of Belgrade, Faculty for Transport and Traffic Engineering, \\ Belgrade, Republic of Serbia, \\ e-mail: m.kilibarda@sf.bg.ac.rs, \\ ORCID iD: (Dhttps://orcid.org/0000-0003-3794-7380 \\ ' University of Belgrade, Faculty for Transport and Traffic Engineering, \\ Belgrade, Republic of Serbia, \\ e-mail:m.kapetanovic@sf.bg.ac.rs, \\ ORCID iD: 『https://orcid.org/0000-0002-5703-6536
}

DOI: 10.5937/vojtehg67-18508; https://doi.org/10.5937/vojtehg67-18508

\author{
FIELD: Mathematics, Logistics, Traffic Engineering \\ ARTICLE TYPE: Original Scientific Paper \\ ARTICLE LANGUAGE: English
}

\section{Summary:}

The aim of the paper is to make an analysis of the efficiency of selected transport units in the military logistics and military vehicles in carrying out the tasks of cargo transport using the method of stochastic frontier analysis (SFA) and the data envelopment analysis (DEA), and creating the basis for further investigation of the parameters that influence the efficiency of military transport units and military vehicles. The research was carried out in ten military transport units intended for the realization of tasks dealing with the logistic function of movement and transportation. The efficiency analysis was done for military vehicles used for carrying out cargo transportation tasks for the needs of supply and special needs of command, units and military institutions. The data was obtained from the software package used to monitor the exploitation of military motor vehicles in the period of one calendar year. The results show that the method selection has a major impact on the obtained technical efficiency 
assessments, and therefore on possible management decisions based on the performed efficiency analysis.

Key words: efficiency, military transport units, military vehicles, data envelopment analysis, stochastic frontier analysis.

\section{Introduction}

A modern military organization together with its missions and tasks in the function of state defense cannot be imagined without its dynamic determinant i.e. its transport and transportation system that allows it to be mobile in its totality or in its parts. Increasing transport needs and demands as products of more dynamic engagement of the military in modern conditions, with a tendency of increasing efficiency and reducing operating costs, make it complicated because of the existing organizational structure of the management and transport units.

In the economy and society in general as well as in the military, logistic processes are an important factor in the functioning of the organization. The performance of the entire logistic system depends largely on the performance of the transport system as its segment. The efficiency of transport is thus imposed as a necessity in order to create a predisposition of the defense system in response to the contemporary challenges and threats to security in accordance with the needs and possibilities of the state.

Efficiency is a very important indicator of a company business analysis and it is one of the most basic and most used performances (Andrejić et al, 2016). The essence of measuring efficiency in transport is to improve efficiency.

The aim of this paper is to carry out an analysis of the efficiency of selected transport units in the military logistics and military vehicles in carrying out cargo handling tasks using the method of stochastic frontier analysis (SFA) and the data envelopment analysis (DEA) in order to create a basis for further research of the parameters that influence the efficiency of the work of the military transport units and military vehicles.

The research was, therefore, carried out in ten military transport units intended for the realization of tasks in the logistic function of movement and transportation. The efficiency analysis was carried out for military vehicles used for carrying out cargo transportation tasks for the needs of supply and special needs of command, units and military institutions. The actual data obtained from the software package used to monitor the use and exploitation of military motor vehicles were used, and they relate to a period of one calendar year. 
The efficiency analysis was realized at three levels: first level efficiency of transport units, second level - vehicle efficiency, and third level - vehicle efficiency within defined classes (clusters). The DEA and SFA methods were used to evaluate and analyze the efficiency of transport units and vehicles. First, the selected decision units (DMUs) of relative efficiency were also defined. Then, the input and output parameters suitable for assessing the relative technical efficiency of the selected DMUs were determined, and then the corresponding DEA and SFA models were selected. Finally, the DEA and SFA models were solved and the results analyzed and interpreted.

Besides the introduction, the paper consists of four chapters. The second chapter provides the basic remarks on the functioning of transport in the defense system and defines the concept of efficiency. The third chapter describes the SFA and DEA methods used in the work to evaluate efficiency. The selection of the input and output parameters and the results of the analysis are given in the fourth chapter. Finally, the conclusion and directions for future research are given in the last chapter.

Transportation function in the defense system and the definition of the concept of efficiency

In accordance with the Rulebook on Transportation of Personnel and Assets in the Ministry of Defense and the Serbian Armed Forces (hereinafter: the Rulebook on Transportation) (Službeni vojni list, 9/2013), transportation of personnel and assets in the Ministry of Defense and the Serbian Armed Forces (hereinafter: transport) is performed by units and institutions of the Serbian Armed Forces and the Ministry of Defense dealing with the tasks of transporting personnel and assets for their own needs, or for the needs of other units and institutions in the Ministry of Defense and the Serbian Armed Forces.

According to the Rulebook on Transportation (Službeni vojni list, 9/2013), the objectives of the movement and transportation function are to provide conditions for satisfying transport needs of the Ministry of Defense and the Serbian Armed Forces, the continuous performance of transport tasks, as well as the economy, efficiency and effectiveness of transport.

The general tasks of the movement and transportation management encompass monitoring, analyzing and proposing measures for improving the organization and use of transport and transport capacities of the army (Dozet et al, 1988). 
According to the Rule on Transportation (Službeni vojni list, 9/2013), the principles of effectiveness and efficiency are:

- the principle of effectiveness which means that the planning and realization of transport allow full satisfaction of the transport needs of the military;

- principle of efficiency, which means that the transportation needs of the army are met in a timely and efficient manner by using the comparative advantages of each of the aspects and modes of transport.

On the other hand, in the Vujaklija's Leksikon stranih reči i izraza (Vujaklija, 1980), efficiency (lat. Efficacitas) is "action, activity, craftiness, success"; while the term "effectiveness" is not mentioned. Gleason and Barnum (1982) emphasize that the term "effectiveness" often means the degree of accomplishment of goals ("doing the right things"), and under the term efficiency - achieving these goals in the best way ("doing things in the right way") (Andrejić \& Kilibarda, 2017).

The efficiency of the vehicle refers to the minimal energy consumption achieved by the design of the vehicle, but also by the technologies of their use. (Andrejic \& Kilibarda, 2017).

The use of military vehicles is carried out on the basis of acts of command (orders, commands, instructions) or approved plans of use or extracts from these plans. By coordinating the planning of the use of military vehicles, the capabilities of the planner and the needs of the users are coordinated, so that the same number of military vehicles accomplishes a greater number of tasks during the day.

Planning in peace, organization and monitoring of the operation of transport means are performed in accordance with tasks such as transport of people and transport of cargo.

The paper analyzes the efficiency of only vehicles used for the realization of cargo transportation tasks for the needs of supply and the special needs of the commands, units and institutions of the Ministry of Defense and the Serbian Armed Forces, all of which are freight cars and terrain vehicles for towing and transport, regardless of their specific purpose, and according to the plan of the competent body for organization and planning of transport and transport.

\section{Methods}

\section{Data Envelopment Analysis - DEA}

In addition to using traditional measures, the assessment of the organization's performance can be carried out using parametric and nonparametric techniques. In practice, it is often necessary to consider 
multiple inputs and outputs that are diverse by their nature (financial, technical, environmental) and are expressed in different measuring units. Farel's technical efficiency measure (Farrell, 1957) allows the inclusion of either multiple inputs or multiple outputs in the analysis. This macroeconomic theory served as the basis for the development of the Data Envelopment Analysis (DEA) as a methodology for assessing efficiency.

The DEA method creators (Charnes et al, 1978) assumed that in assessing the efficiency of units there should not be an objective procedure for determining the values of weight coefficients. By subsequent analysis, it is possible to show which of the units considered are efficient and which are not. The DEA is a mathematical programming technique that allows determining whether the entity, based on data on its inputs and outputs, is efficient or not, relative to other entities involved in the analysis.

There are a large number of models, given in detail in the overview published on the occasion of 30 years of the development of the DEA method (Cook \& Seiford, 2009). The basic models and basic extensions are described in detail in the doctoral dissertation (Martić, 1999) published at the Faculty of Organizational Sciences.

\section{$D E A$ models with constant returns to scale}

Let $x_{i j}$ - the observed amount of input of the i-th type for $\mathrm{DMU}_{\mathrm{j}}\left(\mathrm{x}_{\mathrm{ij}}>\right.$ $0, i=1,2, \ldots, m, j=1,2, \ldots, n)$, and $y_{i j}$ the observed amount of the output $r$-th type of $\mathrm{DMU}_{\mathrm{j}}\left(\mathrm{y}_{\mathrm{rj}}>0, \mathrm{r}=1,2, \ldots, \mathrm{s}, \mathrm{j}=1,2, \ldots, \mathrm{n}\right)$. Charnes, Cooper and Rouds proposed in (Charnes et al, 1978) that for each $\mathrm{DMU}_{\mathrm{k}}, \mathrm{k}=1,2, \ldots, \mathrm{n}$, the optimization task, known as CCR model, MODEL (M.1), should be solved:

$$
(\max ) \mathrm{h}_{\mathrm{k}}=\frac{\sum_{r=1}^{s} u_{r} y_{r k}}{\sum_{i=1}^{m} v_{i} x_{i k}}
$$

subject to:

$$
\begin{gathered}
\frac{\sum_{r=1}^{s} u_{r} y_{r j}}{\sum_{i=1}^{m} v_{i} x_{i j}} \leq 1, j=1,2, \ldots ., n \\
u_{r} \geq 0, r=1,2, \ldots, s
\end{gathered}
$$




$$
v_{i} \geq 0, i=1,2, \ldots, m
$$

where: $h_{k}$ - is the relative efficiency of k-th DMU; $n$ - the number of DMUs to be compared; $m$ - the number of inputs; $s$ - the number of outputs; $u_{r}$ - the weight coefficient for the output $r ; v_{i}$ - the weight coefficient for the input i.

The relative efficiency of $h_{k}$ for $D M U_{k}$ is defined as the ratio of the weights of its outputs (virtual output) and the weights of its inputs (virtual input). The CCR ratio model calculates total technical efficiency that includes both pure technical efficiency and efficiency as a result of different business volumes.

Since condition (2) is valid for the k-th DMU required for the maximum efficiency (1), it is obvious that $0<h_{k} \leq 1$. If the value for $h_{k}$ in the function of the target is equal to 1 , then the DMU is relatively efficient, and if it is less than 1, the $D M U_{k}$ is relatively inefficient and the value of $h_{k}$ shows how many percent of this unit needs to reduce its inputs.

The linear fractional programming problem, described by relations (1) - (4), can be reduced to an equivalent linear program using simple Charns-Cooper transformations (Cooper et al, 1999) - MODEL (M.2):

$$
(\max ) h_{k}=\sum_{r=1}^{s} u_{r} y_{r k}
$$

subject to:

$$
\begin{gathered}
\sum_{i=1}^{m} v_{i} x_{i k}=1 \\
\sum_{r=1}^{s} u_{r} y_{r j}-\sum_{i=1}^{m} v_{i} x_{i j} \leq 0, j=1,2, \ldots, n \\
v_{i} \geq \varepsilon, i=1,2, \ldots, m \\
u_{r} \geq \varepsilon, r-1,2, \ldots, s
\end{gathered}
$$

In the M.2 model for k-th DMU, the virtual output is maximized and its virtual input is equal 1 . The limitations by the data relation (5) indicate that the optimal weights for the k-th DMU must satisfy the requirement that for each of the DMUs its virtual output cannot be larger than its virtual input. 


\section{$D E A$ model with variable returns to scale}

The first extension of the core CCR DEA model was introduced by Banker, Charnes and Cooper (Banker et al, 1984). The BCC model measures pure technical efficiency, i.e. it gives an efficiency measure that ignores the impact of the volume of operations by comparing the k-th DMU with other units of the same size.

In relation to the CCR model, the primary $\mathrm{BCC}$ model contains an additional variable in $\mathrm{u}_{*}$ which defines the position of an auxiliary hyper plane that lies on or above each DMU included in the analysis. The value of the parameter $u_{*}$ directly indicates the nature of the economies of scale allowed by the DEA model. This is shown in the theorem that Banker and Thrall proved in (Banker \& Thrall, 1992).

The primary BCC DEA model proposed in (Banker et al, 1984) has the following form - MODEL M.3:

$$
(\max ) h_{k}=\sum_{r=1}^{s} u_{r} y_{r k}+u_{*}
$$

subject to:

$$
\begin{gathered}
\sum_{i=1}^{m} v_{i} x_{i k}=1 \\
\sum_{r=1}^{s} u_{r} y_{r j}-\sum_{i=1}^{m} v_{i} x_{i j}+u_{*} \leq 0, j=1,2, \ldots, n \\
v_{i} \geq \varepsilon, i=1,2, \ldots, m \\
u_{r} \geq \varepsilon, r-1,2, \ldots, s
\end{gathered}
$$

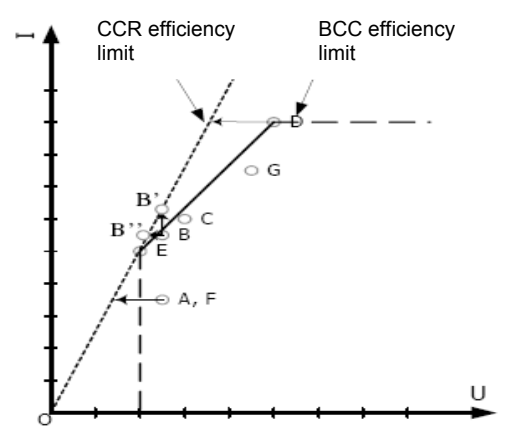

Figure 1 - Forms of efficiency limit

Puс. 1 - Пределы эфрфективности Слика 1 - Облици границе ефикасности 
The orientation of the DEA model (input or output) determines the direction of the ineffective DMU projection to the efficiency limit. In an input-oriented model, efficiency improves through a proportional input reduction, and the output orientation requires a proportional increase in output.

\section{Stochastic Frontier Analysis - SFA}

The SFA is a statistical parametric technique used to estimate deviations in the performance of production units from the production frontier (Aigner et al, 1977) and (Meeusen \& Van den Broeck, 1977). The basic concept of the SFA model is that deviations are not entirely due to inefficiencies, as they confirm that random effects beyond unit control can affect production. The main advantage of the SFA is that it can isolate the contribution of random effects to variations in technical efficiency.

The original specification of the model included the production function defined for crosssectional data, and later it received a number of different modifications and shapes. The function contained an error component, consisting of two elements - noise (random errors) and technical inefficiency. This model, in the case of Cobb-Douglas frontier function, has the following form:

$$
\ln \left(y_{i}\right)=\beta_{0}+\sum_{k=1}^{K} \beta_{k} \ln \left(x_{i k}\right)+v_{i}-u_{i}
$$

where: $y_{i}$ - the output (production) of the $i$-th company; $x_{i k}-k$-th input of the i-th firm $(\mathrm{k}=1, \ldots, \mathrm{k}) ; \beta_{\mathrm{k}}$ - an unknown parameter to be evaluated $(\mathrm{k}=$ $1, \ldots, \mathrm{K}) ; \mathrm{v}_{\mathrm{i}} \sim \mathrm{N}\left(0, \sigma_{\mathrm{v}}{ }^{2}\right)$ is a random variable that represents fault (noise) and has an independent distribution of the distribution of technical inefficiency; $u_{i} \sim\left|N\left(0, \sigma_{v}{ }^{2}\right)\right|$ - a non-negative random variable that represents technical inefficiency.

For example, the input values are displayed on the $x$-axis and the output values on the $y$-axis. The firm $A$ uses the input $x_{A}$ to generate the output $q_{A}$ (indicated by $x$ ), while the firm $B$ uses the input $x_{B}$ to generate the output $q_{B}$ (shown by $x$ ). If there are no inefficiency effects, i.e. if $\left(u_{A}=0, u_{B}=0\right)$, then the so-called exits of the frontier area are $q_{A}^{*}=\exp \left(\beta_{0}+\beta_{1} \ln x_{A}+v_{A}\right)$ and $q_{B}^{*}=\exp \left(\beta_{0}+\beta_{1} \ln x_{B}+v_{B}\right)$. In Figure

2 , these values are represented by the sign $\otimes$. Obviously, the frontier exit of $A$ is above the deterministic part of the frontier region because the effect of the statistical noise is positive $v_{A}>0$, and the B-frontier output is 
below, because the effect of the statistical noise is negative $v_{B}<0$ (Kumbhakar \& Knox Lovell, 2003).

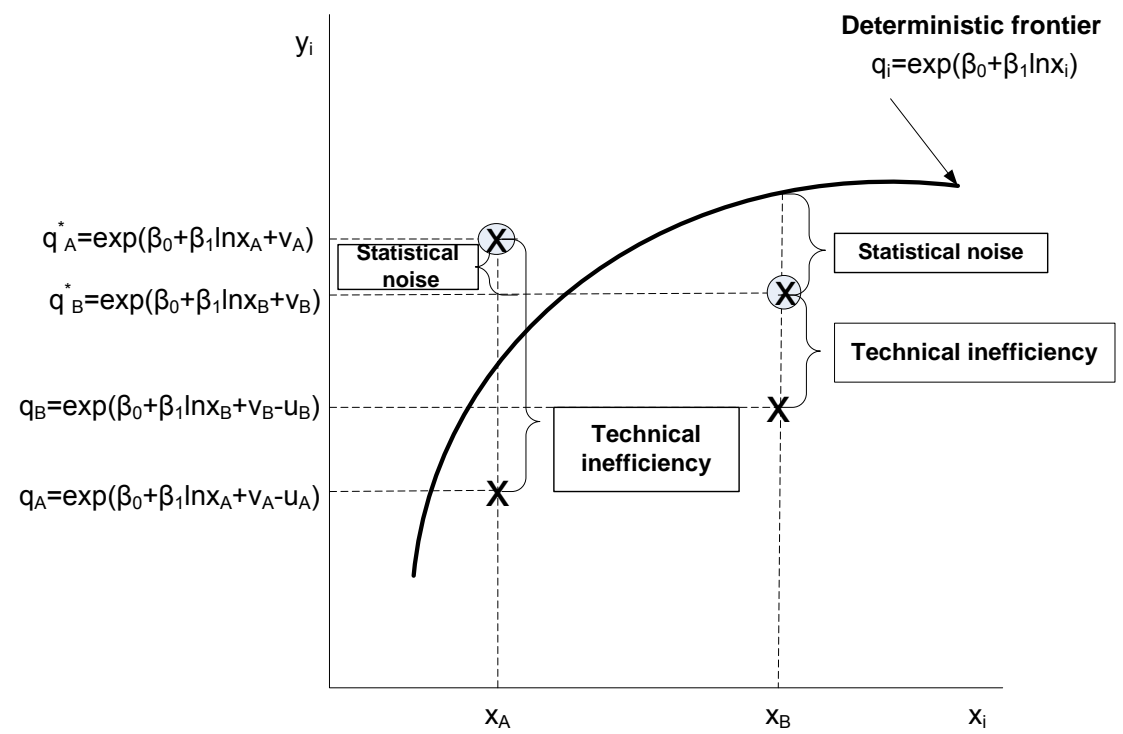

Figure 2 - Kob-Douglas model Puc. 2 - Модель Кобба-Дугласа Слика 2 - Коб-Дагласов модел

Function modifications included additional assumptions regarding the distribution of technical inefficiencies $u_{i}$, such as a truncated normal or gamma distribution; other forms of the frontier function; consideration of panel data and technical efficiencies variability in time; expanding models with cost functions, etc.

Although it contains a number of parameters to be assessed against the Cobb-Douglas function, the transcedental logarithmic form of the frontier form of the function is much more flexible and provides more consistent technical efficiency estimates. It represents the generalization of the Cobb-Douglas function, and has the following form (Knežević et al, 2015):

$$
\ln \left(y_{i}\right)=\beta_{0}+\sum_{k=1}^{K} \beta_{k} \ln \left(x_{i k}\right)+\sum_{k=1}^{K} \sum_{k^{\prime}=1}^{K} \beta_{k k^{\prime}} \ln \left(x_{i k}\right) \ln \left(x_{i k^{\prime}}\right)+v_{i}-u_{i}
$$

The main disadvantage of standard SFA models is the inability to observe multiple outputs, i.e. the existence of only one output. Coelli and Perelman (Coelli \& Perelman 1996, 2000), Knezević, Bojović, 
Kapetanović (Knezević et al, 2015) dealt with the frontier function in the case of multiple inputs and multiple outputs. In the case of the existence of the $\mathrm{K}$ input and the $\mathrm{L}$ output, the functional form can be written as:

$$
\begin{aligned}
& -\ln \left(y_{L}\right)=\alpha_{0}+\sum_{k=1}^{K} \alpha_{k} \ln \left(x_{k}\right)+\sum_{l=1}^{L-1} \beta_{l} \ln \left(\frac{y_{l}}{y_{L}}\right)+\frac{1}{2} \sum_{k=1}^{K} \sum_{k^{\prime}=1}^{K} \alpha_{k k^{\prime}} \ln \left(x_{k}\right) \ln \left(x_{k^{\prime}}\right)+ \\
& +\sum_{k=1}^{K} \sum_{l=1}^{L-1} \gamma_{k l} \ln \left(x_{k}\right) \ln \left(\frac{y_{l}}{y_{L}}\right)+\frac{1}{2} \sum_{l=1}^{L-1} \sum_{l^{\prime}=1}^{L-1} \beta_{l l}, \ln \left(\frac{y_{l}}{y_{L}}\right) \ln \left(\frac{y_{l},}{y_{L}}\right)+v_{i}-u_{i}
\end{aligned}
$$

where $\mathrm{y}_{\mathrm{L}}$ represents an arbitrary chosen output. In the case of two entrances and two exits:

$$
\begin{aligned}
& -\ln \left(y_{1}\right)=\alpha_{0}+\alpha_{1} \ln \left(x_{1}\right)+\alpha_{2} \ln \left(x_{2}\right)+\beta_{1} \ln \left(\frac{y_{2}}{y_{1}}\right)+\frac{1}{2} \alpha_{3} \ln ^{2}\left(x_{1}\right)+ \\
& +\frac{1}{2} \alpha_{4} \ln ^{2}\left(x_{2}\right)+\frac{1}{2} \alpha_{5} \ln \left(x_{1}\right) \ln \left(x_{2}\right)+\gamma_{1} \ln \left(x_{1}\right) \ln \left(\frac{y_{2}}{y_{1}}\right)+ \\
& +\gamma_{2} \ln \left(x_{2}\right) \ln \left(\frac{y_{2}}{y_{1}}\right)+\frac{1}{2} \beta_{2} \ln ^{2}\left(\frac{y_{2}}{y_{1}}\right)+v_{1}-u_{1}
\end{aligned}
$$

\section{Selection of parameters and the efficiency analysis}

In order to improve the efficiency of the organization's work, it is necessary to select relevant indicators whose monitoring and analysis can provide the necessary information in order to generate actions to improve the process and improve the efficiency of the organization's operation.

Transport is a process characterized by high costs: number of vehicles and drivers, energy consumption, realized transport work, space and time use of the vehicle, are just some of the factors that influence the efficiency of the transport process.

The goal of transportation planning, due to the specific nature of the military organization, is to find the conditions for meeting the transport needs of units and military institutions, regardless of the respect of other transport principles: rationality, economy, etc. For these reasons, there are cases of inefficient use of vehicles.

The basic efficiency criteria should contribute to meeting the goal of the existence of a system - meeting the transport needs of the army in peace, during the mobilization period and in the war. The basic criteria of transport in general can be taken as the basic criteria of efficiency for achieving these goals - the performance of the fleet and the cost of transport services, since most of the parameters of the transport process are related to them. The performance of the transport fleet of transport units is assessed with two interconnected parameters of the incineration 
criterion; the volume of transported cargo (volume of transport) in tonnes and the number of tonne-kilometers achieved (cargo traffic) in tkm (Dozet et al, 1988).

The indicators of efficiency in transport in literature:

Byrne and Markham (1991): tkm / total transport costs, transported quantity / total transport costs, total transport capacity / capacity costs.

Cruijssen et al (2010): labor power (salaries, driver experience, total hours of work, number of employees), equipment (number of trucks, number of trailers, total capacity), intangible assets (market information, contact with users), profit.

Kim (2010): costs of employees, fuel costs, lubricant costs, taxes, insurance, mileage, transported quantity, transport distance.

The division of the indicators of the efficiency of logistics processes can also be carried out according to the subsystem or process described by Andrejić and Kilibarda (2017). Thus, groups of indicators can be distinguished:

- storage indicators;

- transport indicators (number of vehicles, total number of kilometers traveled, realized transport work, fuel consumption, etc.);

- stock indicators.

The data used in the paper were collected through an application intended for automated processing of data on the condition and use of non-combat vehicles and connecting vehicles and other fuel consumers in the information system of the traffic service in the military. This application allows tracking the traveled route, fuel used, the number of persons transported and the amount of transported cargo for a specified period of time (month, year) for the vehicle or the entire unit.

Data on the performance indicators of military transport units and vehicles which can be obtained from the above application coincide with the often used indicators of efficiency in transport in the literature, first of all in the book Efficiency of Logistic Processes (Andrejić \& Kilibarda, 2017). For this reason, the following data were used in the analysis of the efficiency of the observed military transport units and vehicles - Table 1.

Two input parameters were used to evaluate the efficiency of the transport units: the number of vehicles used for the transport of cargo and the total fuel consumption of these vehicles (I). Two parameters were also used as output indicators: the total distance driven by vehicles used for transport of goods $(\mathrm{km})$ and the total quantity of transported cargo $(\mathrm{t})$.

For the assessment of the efficiency of vehicles (in total and by classes), the parameters were used - two inputs: total fuel consumption per vehicle (I) and total available vehicle load for the days of use in the 
observed time $(\mathrm{t})$ and two outputs: distance driven per vehicle $(\mathrm{km})$ and the total quantity of cargo carried per vehicle (t).

Table 1 - Aspects of measuring the efficiency of transport

Таблица 1 - Аспекты измерения эффрективности транспорта

Табела 1 - Аспекти мерења ефрикасности транспорта

\begin{tabular}{|c|c|c|c|}
\hline & $\begin{array}{l}\text { Efficiency of } \\
\text { transport unit }\end{array}$ & $\begin{array}{l}\text { Efficiency of the } \\
\text { vehicle }\end{array}$ & Vehicle efficiency by class \\
\hline $\begin{array}{l}\text { Management } \\
\text { level }\end{array}$ & $\begin{array}{c}\text { Operating } \\
\text { level }\end{array}$ & Tactical level & Tactical level \\
\hline $\begin{array}{c}\text { Input } \\
\text { indicators }\end{array}$ & $\begin{array}{l}\text { 1. number of } \\
\text { vehicles } \\
\text { 2. fuel (I) }\end{array}$ & $\begin{array}{l}\text { 1. fuel }(\mathrm{I}) \\
\text { 2. the total } \\
\text { available } \\
\text { vehicle load in } \\
\text { the observed } \\
\text { time }(\mathrm{t})\end{array}$ & $\begin{array}{l}\text { 1. fuel }(I) \\
\text { 2. the total available vehicle load } \\
\text { in the observed time }(\mathrm{t})\end{array}$ \\
\hline $\begin{array}{l}\text { Output } \\
\text { indicators }\end{array}$ & $\begin{array}{l}\text { 1. distance } \\
\text { driven }(\mathrm{km}) \\
\text { 2. transported } \\
\text { cargo }(\mathrm{t})\end{array}$ & $\begin{array}{l}\text { 1. } \text { distance } \\
\text { driven }(\mathrm{km}) \\
\text { 2. transported } \\
\text { cargo }(\mathrm{t})\end{array}$ & $\begin{array}{l}\text { 1. distance driven }(\mathrm{km}) \\
\text { 2. transported cargo }(\mathrm{t})\end{array}$ \\
\hline $\begin{array}{c}\text { DMU } \\
\text { number }\end{array}$ & $\begin{array}{c}10 \text { transport } \\
\text { units }\end{array}$ & 173 vehicles & $\begin{array}{c}6 \text { class vehicles: } \\
24 \text { vehicles up to } 3 t \text { capacity } \\
78 \text { vehicles up to } 6 t \text { capacity } \\
17 \text { vehicles up to } 12 t \text { capacity } \\
11 \text { vehicles over } 12 t \text { capacity } \\
21 \text { vehicle } A C G \\
22 \text { vehicles } A C V\end{array}$ \\
\hline $\begin{array}{l}\text { Applied } \\
\text { model }\end{array}$ & \multicolumn{3}{|c|}{ DEA and SFA analysis } \\
\hline
\end{tabular}

The vehicle classes are defined according to load capacity (up to 3t, from $3 t$ to $6 t$, from $6 t$ to $12 t$ and over 12t) and the specific type of cargo being transported by them (ACG - fuel tanks and ACV - water tank), Table 2. In this analysis, vehicles used for fewer than 10 working days and covering fewer than 500 kilometers during the year were not observed.

The paper analyzes the relative technical efficiency of ten military transport units and 173 vehicles engaged in cargo transportation tasks for supplies and special needs of the army.

It should be emphasized that until now, to a certain extent, mainly through the annual analysis of logistics in the military, the problem of organization and structure of transport units and their efficiency was partially taken into account, but not comprehensively approached in the research of the subject matter. 
Table 2 - Overview of the number of vehicles by classes and units Таблица 2 - Обзор количества транспортных средств по классам и единицам Табела 2 - Преглед броја возила по класама и јединицама

\begin{tabular}{|l|l|l|l|l|l|l|l|}
\hline & up to 3t & up to 6t & up to 12t & over 12t & ACG & ACV & TOTAL \\
\hline DMU 1 & 2 & 9 & 1 & 5 & 0 & 0 & 17 \\
\hline DMU 2 & 0 & 12 & 1 & 0 & 1 & 2 & 16 \\
\hline DMU 3 & 0 & 7 & 3 & 3 & 3 & 0 & 16 \\
\hline DMU 4 & 2 & 4 & 3 & 2 & 3 & 0 & 14 \\
\hline DMU 5 & 3 & 5 & 1 & 1 & 1 & 3 & 14 \\
\hline DMU 6 & 2 & 8 & 1 & 0 & 0 & 3 & 14 \\
\hline DMU 7 & 2 & 10 & 4 & 0 & 5 & 9 & 30 \\
\hline DMU 8 & 3 & 7 & 1 & 0 & 6 & 2 & 19 \\
\hline DMU 9 & 3 & 4 & 0 & 0 & 1 & 2 & 10 \\
\hline DMU 10 & 7 & 12 & 2 & 0 & 1 & 1 & 23 \\
\hline TOTAL & 24 & 78 & 17 & 11 & 21 & 22 & 173 \\
\hline
\end{tabular}

Table 3 - Descriptive input and output statistics for transport units

Таблица 3 - Описательная статистика ввода и вывода транспортных единиц Табела 3 - Дескриптивна статистика улаза и излаза за транспортне јединице

\begin{tabular}{|l|l|l|l|l|l|l|l|l|}
\hline & I/O & Parameter & Var & Obs & Mean & $\begin{array}{l}\text { Std. } \\
\text { Dev. }\end{array}$ & Min & Max \\
\hline \multirow{5}{*}{ DMU } & output & $\begin{array}{l}\text { distance } \\
\text { driven (km) }\end{array}$ & $\mathrm{y} 1$ & 10 & 137133.3 & 68275.3 & 62682 & 296695 \\
\cline { 2 - 9 } & output & $\begin{array}{l}\text { transported } \\
\text { cargo (t) }\end{array}$ & $\mathrm{y} 2$ & 10 & 4156.7 & 4694.2 & 808 & 15763 \\
\cline { 2 - 9 } & input & fuel (l) & $\mathrm{x} 1$ & 10 & 35138.5 & 19019.4 & 16717 & 78223 \\
\cline { 2 - 9 } & input & $\begin{array}{l}\text { the number } \\
\text { of vehicles }\end{array}$ & $\mathrm{x} 2$ & 10 & 17.3 & 5.6 & 10 & 30 \\
\hline
\end{tabular}

The calculation of the efficiency of transport units and vehicles was done whith:

- Input CCR and BCC DEA models - DEAP Version 2.1 software used for calculating (Softver DEAP Version 2.1., 2018).

- SFA model (using (6)), halfnormal and truncatednormal distribution - STATA13 software used for calculating (Softver STATA13, 2018).

The input-oriented model was selected as transport unit managers can influence more the reduction of input (the number and type of vehicles used, i.e. fuel consumption and vehicle load), and less the increase of output (quantity of transported cargo).

The DEA CCR model, which shows only three efficient units, has the greatest discriminatory power. On the other hand, the SFA model, with the assumed distribution of technical inefficiency, recognizes all units as effective. 
As said, the SFA model, with the hnorm and tnorm distribution, recognizes all units as efficient. The DEA BCC model recognizes three (conditionally two) inefficient units, while the DEA CCR model recognizes only three units as effective - DMU3, DMU6 and DMU8 and therefore has the highest discriminatory power - Table 4.

Table 4 - Results of the analysis of the efficiency of transport units

Таблица 4 - Результаты анализа эффрективности транспортных единиц Табела 4 - Резултати анализе ефикасности транспортних јединица

\begin{tabular}{|l|l|l|l|l|l|l|l|l|}
\hline & $\begin{array}{l}\text { DEA } \\
\text { CCR }\end{array}$ & $\begin{array}{l}\text { DEA } \\
\text { BCC }\end{array}$ & $\begin{array}{l}\text { SFA } \\
\text { tnorm }\end{array}$ & $\begin{array}{l}\text { SFA } \\
\text { hnorm }\end{array}$ & $\begin{array}{l}\text { DEA } \\
\text { CCR }\end{array}$ & $\begin{array}{l}\text { DEA } \\
\text { BCC }\end{array}$ & $\begin{array}{l}\text { SFA } \\
\text { tnorm }\end{array}$ & $\begin{array}{l}\text { SFA } \\
\text { hnorm }\end{array}$ \\
\hline & & & & & \multicolumn{5}{|c|}{ rank } \\
\hline DMU1 & 0.727 & 0.798 & 0.998363 & 0.999526 & 10 & 10 & 1 & 10 \\
\hline DMU2 & 0.771 & 1 & 0.998362 & 0.999545 & 9 & 1 & 7 & 2 \\
\hline DMU3 & 1 & 1 & 0.998362 & 0.999547 & 1 & 1 & 7 & 1 \\
\hline DMU4 & 0.997 & 1 & 0.998363 & 0.999526 & 4 & 1 & 1 & 9 \\
\hline DMU5 & 0.856 & 0.961 & 0.998363 & 0.999534 & 7 & 9 & 1 & 6 \\
\hline DMU6 & 1 & 1 & 0.998362 & 0.999528 & 1 & 1 & 7 & 8 \\
\hline DMU7 & 0.983 & 1 & 0.998363 & 0.999535 & 5 & 1 & 1 & 5 \\
\hline DMU8 & 1 & 1 & 0.998362 & 0.999536 & 1 & 1 & 7 & 4 \\
\hline DMU9 & 0.773 & 1 & 0.998363 & 0.999537 & 8 & 1 & 1 & 3 \\
\hline DMU10 & 0.968 & 0.999 & 0.998363 & 0.999531 & 6 & 8 & 1 & 7 \\
\hline
\end{tabular}

Thus, the comments on the results obtained are as follows. The average efficiency of transport units by models is:

DEA CCR-0.91 <DEA BCC-0.98 <SFA tnorm $1.00<$ SFA hnorm $\sim 1.00$

DMU8 and DMU6, as efficient, do not have a high-capacity vehicle (tow truck). The greatest contribution to the efficiency of DMU8 is a vehicle marked mv127 ACG which was used to transport by far the largest amount of cargo - 13613t (i.e. liters of fuel). Without the mentioned vehicle, DMU8 would have had efficiency of 0.847 under the CCR model, and 0.849 according to the BCC model, i.e. it would not be at the limit of efficiency. DMU8 transported the largest amount of cargo.

DMU3 does not have a vehicle carrying capacity of up to 3t or ACV. Only one of the four units with high-capacity vehicles was declared effective (DMU3). It is interesting to note that the lowest efficiency in both the CCR and BCC model is DMU1, with a percentage of the largest number of heavy-duty vehicles (trucks) being $29 \%$ of the vehicle unit.

DMU2 is inefficient even though there are no vehicles with high load capacity, and the highest number of used vehicles is $3 t$ to $6 t$ capacity $(75 \%)$. Also, DMU2 covered the fewest number of kilometers and transported the smallest amount of cargo. The reason for relative 
inefficiency of DMU9 can be the size of the unit (the smallest number of vehicles), besides being the third transport unit in one region. The largest number of kilometers covered is in DMU7, but it is not at the limit of efficiency because it is the unit with the largest number of vehicles used.

If the efficiency of transport units is analyzed through the average efficiency of the observed vehicles of the transport units, given in Table 5 , the lowest results of efficiency are still given by the DEA CCR: DEA CCR-0.37<DEA BCC-0.46 <SFA hormone -0.74 <SFA tnorm -0.8

Table 5 - Average efficiency of vehicles by transport units

Таблица 5 - Средняя эфффективность транспортных средств по транспортным единицам

Табела 5 - Просечна ефикасност возила по транспортним јединицама

\begin{tabular}{|l|l|l|l|l|l|l|l|l|l|}
\hline & $\begin{array}{l}\text { DEA } \\
\text { CCR }\end{array}$ & $\begin{array}{l}\text { DEA } \\
\text { BCC }\end{array}$ & $\begin{array}{l}\text { SFA } \\
\text { tnorm }\end{array}$ & $\begin{array}{l}\text { SFA } \\
\text { hnorm }\end{array}$ & $\begin{array}{l}\text { DEA } \\
\text { CCR }\end{array}$ & $\begin{array}{l}\text { DEA } \\
\text { BCC }\end{array}$ & $\begin{array}{l}\text { SFA } \\
\text { tnorm }\end{array}$ & $\begin{array}{l}\text { SFA } \\
\text { hnorm }\end{array}$ \\
\hline & & & & & \multicolumn{5}{|c|}{ rank } \\
\hline DMU1 & 0.33 & 0.42 & 0.82 & 0.75 & 8 & 8 & 5 & 5 \\
\hline DMU2 & 0.31 & 0.51 & 0.85 & 0.79 & 10 & 3 & 1 & 1 \\
\hline DMU3 & 0.31 & 0.37 & 0.83 & 0.77 & 9 & 10 & 2 & 3 \\
\hline DMU4 & 0.42 & 0.51 & 0.76 & 0.67 & 2 & 2 & 9 & 9 \\
\hline DMU5 & 0.37 & 0.49 & 0.81 & 0.74 & 5 & 4 & 7 & 7 \\
\hline DMU6 & 0.46 & 0.53 & 0.71 & 0.65 & 1 & 1 & 10 & 10 \\
\hline DMU7 & 0.41 & 0.45 & 0.79 & 0.72 & 3 & 7 & 8 & 8 \\
\hline DMU8 & 0.39 & 0.47 & 0.81 & 0.74 & 4 & 5 & 6 & 6 \\
\hline DMU9 & 0.33 & 0.41 & 0.83 & 0.76 & 6 & 9 & 3 & 4 \\
\hline DMU10 & 0.33 & 0.47 & 0.83 & 0.78 & 7 & 6 & 4 & 2 \\
\hline
\end{tabular}

Somewhat higher results of vehicle efficiency in the SFA model are obtained for the assumed truncatednormal relative to the halfnormal distribution of technical inefficiency. The DEA CCR model yields less efficacy results than the DEA BCC, as it assumes constant returns to scale.

By analyzing the obtained average efficiency of vehicles used by transport units, it is noticed that DMU6 is still the most efficient for both DEA models, but according to the SFA models it has the worst results. Observing the results in this way, the SFA models rated DMU2 as the most efficient, which, according to DEA CCR, I has the worst results of vehicle efficiency, and the opposite case is with DMU3.

When the number of vehicles used is taken as the input parameter, the results of the efficiency of transport units differ from the results obtained when the average values of the efficiency of the vehicles used for the transport within the unit are observed. 
It is noted that the efficiency of the vehicles is small, which can be explained by using a vehicle for transporting freight often without the criterion of better utilization of the load (the need for transport has the quantity of cargo within the defined time limit). Out of 173 vehicles observed:

- according to the DEA CCR model, only three vehicles are efficient, as many as 146 vehicles have an efficiency of less than 0.5 , and the average efficiency is 0.37 .

- according to the DEA BCC model, 8 vehicles are effective, 124 vehicles have efficiency lower than 0.5 , and the average efficiency is 0.46 .

- according to the SFA tnorm model, the highest efficiency of 0.94 was found in two vehicles, 54 vehicles have efficiency below average, and the average efficiency is 0.8 .

- according to the SFA hnorm model, one vehicle has the highest efficiency of $0.93,72$ vehicles have efficiency below average, and the average efficiency is 0.74 .

The vehicle carrying capacity up to $3 t$ with the mark mv172 is efficient according to the DEA CCR and BCC models, while it is among the two worst ones in the efficiency evaluation of the SFA models. On the other hand, the ACG vehicle with the mv152 tag has the best efficiency according to the SFA models, while according to the DEA CCR it has the lowest efficiency, and according to the DEA BCC, it is among the least efficient.

Among the most efficient vehicles, there are no vehicles with greater capacity (from $6 \mathrm{t}$ to $12 \mathrm{t}$ and over 12t), and the reasons for this should be sought in the fact that their efficiency is more reflective of the inexorability of their load capacity.

When considering the efficiency of all vehicles in the entire group of 173 vehicles per cluster, Table 7 , it is noted that the vehicles with a minimum carrying capacity of up to $3 \mathrm{t}$ have the highest average efficiency according to the DEA methods, which can be explained with the smallest loss of available load capacity and lower average fuel consumption. 
Table 6-Descriptive statistics of inputs and outputs for vehicles Таблица 6 - Описательная статистика вводов и выводов транспортных средств

Табела 6 - Дескриптивна статистика улаза и излаза за возила

\begin{tabular}{|c|c|c|c|c|c|c|c|c|}
\hline & $\begin{array}{l}\mathrm{l} / \\
\mathrm{O}\end{array}$ & Parameter & Var & Obs & Mean & $\begin{array}{l}\text { Std. } \\
\text { Dev. }\end{array}$ & Min & Max \\
\hline \multirow{4}{*}{$\begin{array}{l}\text { All } 173 \\
\text { vehicles }\end{array}$} & $\mathrm{O}$ & distance driven $(\mathrm{km})$ & a1 & 173 & 7927 & 8249 & 423 & 40576 \\
\hline & $\mathrm{O}$ & transported cargo (t) & a2 & 173 & 240 & 1057 & 5 & 13613 \\
\hline & I & fuel (I) & $\mathrm{b} 1$ & 173 & 2031 & 2059 & 110 & 11531 \\
\hline & I & $\begin{array}{l}\text { available vehicle load } \\
(\mathrm{t})\end{array}$ & b2 & 173 & 379 & 443 & 33 & 3984 \\
\hline \multirow{4}{*}{$\begin{array}{l}\text { Vehicles } \\
\text { up to } 3 t \\
\text { capacity }\end{array}$} & $\mathrm{O}$ & distance driven $(\mathrm{km})$ & ti1 & 24 & 9918 & 10663 & 779 & 39908 \\
\hline & $\mathrm{O}$ & transported cargo $(\mathrm{t})$ & ti2 & 24 & 70 & 82 & 5 & 344 \\
\hline & I & fuel (I) & tu1 & 24 & 1347 & 1243 & 238 & 4728 \\
\hline & I & $\begin{array}{l}\text { available vehicle load } \\
\text { (t) }\end{array}$ & tu2 & 24 & 215 & 180 & 39 & 843 \\
\hline \multirow{4}{*}{$\begin{array}{l}\text { Vehicles } \\
\text { up to } 6 \mathrm{t} \\
\text { capacity }\end{array}$} & $\mathrm{O}$ & distance driven (km) & si1 & 78 & 7430 & 7354 & 423 & 35330 \\
\hline & $\mathrm{O}$ & transported cargo $(\mathrm{t})$ & si2 & 78 & 71 & 77 & 6 & 446 \\
\hline & $\mathrm{I}$ & fuel (I) & su1 & 78 & 1874 & 1653 & 110 & 8107 \\
\hline & I & $\begin{array}{l}\text { available vehicle load } \\
(\mathrm{t})\end{array}$ & su2 & 78 & 290 & 172 & 35 & 800 \\
\hline \multirow{4}{*}{$\begin{array}{l}\text { Vehicles } \\
\text { up to } 12 \mathrm{t} \\
\text { capacity }\end{array}$} & $\mathrm{O}$ & distance driven $(\mathrm{km})$ & di1 & 17 & 7255 & 3975 & $\begin{array}{l}176 \\
7\end{array}$ & 15544 \\
\hline & $\mathrm{O}$ & transported cargo (t) & di2 & 17 & 109 & 80 & 19 & 292 \\
\hline & I & fuel (I) & du1 & 17 & 1981 & 1106 & 523 & 4349 \\
\hline & I & $\begin{array}{l}\text { available vehicle load } \\
(\mathrm{t})\end{array}$ & du2 & 17 & 418 & 243 & 147 & 960 \\
\hline \multirow{4}{*}{$\begin{array}{l}\text { Vehicles } \\
\text { over } 12 \mathrm{t} \\
\text { capacity }\end{array}$} & $\mathrm{O}$ & distance driven $(\mathrm{km})$ & oi1 & 11 & 11099 & 11248 & 927 & 31102 \\
\hline & $\mathrm{O}$ & transported cargo (t) & oi2 & 11 & 557 & 651 & 40 & 1748 \\
\hline & I & fuel (I) & ou1 & 11 & 4172 & 4145 & 385 & 11397 \\
\hline & I & $\begin{array}{l}\text { available vehicle load } \\
(\mathrm{t})\end{array}$ & ou2 & 11 & 970 & 811 & 180 & 2574 \\
\hline \multirow{4}{*}{$\begin{array}{l}\text { Vehicles } \\
\text { ACG }\end{array}$} & $\mathrm{O}$ & distance driven $(\mathrm{km})$ & gi1 & 21 & 7873 & 11330 & 479 & 40576 \\
\hline & $\mathrm{O}$ & transported cargo $(\mathrm{t})$ & gi2 & 21 & 870 & 2938 & 14 & 13613 \\
\hline & I & fuel (I) & gu1 & 21 & 2162 & 2832 & 213 & 11531 \\
\hline & I & $\begin{array}{l}\text { available vehicle load } \\
(\mathrm{t})\end{array}$ & gu2 & 21 & 592 & 894 & 35 & 3984 \\
\hline \multirow{4}{*}{$\begin{array}{l}\text { Vehicles } \\
\text { ACV }\end{array}$} & $\mathrm{O}$ & distance driven $(\mathrm{km})$ & vi1 & 22 & 6498 & 5168 & 487 & 17195 \\
\hline & $\mathrm{O}$ & transported cargo $(\mathrm{t})$ & vi2 & 22 & 370 & 268 & 25 & 980 \\
\hline & I & fuel (I) & vu1 & 22 & 2177 & 1786 & 256 & 6005 \\
\hline & I & $\begin{array}{l}\text { available vehicle load } \\
(\mathrm{t})\end{array}$ & vu2 & 22 & 344 & 226 & 33 & 952 \\
\hline
\end{tabular}


Table 7 - Average efficiency of all vehicles by defined groups

Таблица 7 - Средняя эффрективность всех транспортных средств по определенным группам

Табела 7 - Просечна ефикасност свих возила по дефинисаним групама

\begin{tabular}{|l|l|l|l|l|l|l|l|l|}
\hline $\begin{array}{l}\text { Vehicles } \\
\text { capacity }\end{array}$ & $\begin{array}{l}\text { DEA } \\
\text { CCR }\end{array}$ & $\begin{array}{l}\text { DEA } \\
\text { BCC }\end{array}$ & $\begin{array}{l}\text { SFA } \\
\text { tnorm }\end{array}$ & $\begin{array}{l}\text { SFA } \\
\text { hnorm }\end{array}$ & $\begin{array}{l}\text { DEA } \\
\text { CCR }\end{array}$ & $\begin{array}{l}\text { DEA } \\
\text { BCC }\end{array}$ & $\begin{array}{l}\text { SFA } \\
\text { tnorm }\end{array}$ & $\begin{array}{l}\text { SFA } \\
\text { hnorm }\end{array}$ \\
\hline & & & & & \multicolumn{5}{|c|}{ rank } \\
\hline up to 3t & 0.56 & 0.70 & 0.68 & 0.61 & 1 & 1 & 6 & 6 \\
\hline up to 6t & 0.32 & 0.40 & 0.83 & 0.76 & 5 & 4 & 2 & 3 \\
\hline up to 12t & 0.33 & 0.38 & 0.81 & 0.74 & 4 & 5 & 4 & 4 \\
\hline over 12t & 0.27 & 0.31 & 0.88 & 0.83 & 6 & 6 & 1 & 1 \\
\hline ACG & 0.33 & 0.45 & 0.83 & 0.76 & 3 & 3 & 3 & 2 \\
\hline ACV & 0.45 & 0.58 & 0.78 & 0.72 & 2 & 2 & 5 & 5 \\
\hline
\end{tabular}

According to the SFA method, the vehicles up to 3t capacity have the lowest efficiency. Completely opposing ranking is found in the vehicles carrying over $12 \mathrm{t}$. According to the SFA method, they have the highest efficiency, while according to the DEA methods in both cases they have the lowest average efficiency. Conditional consistency, as far as the average vehicle efficiency rating is concerned, is found in all methods in the case of the groups of ACG vehicles and the vehicle with a carrying capacity from $6 \mathrm{t}$ to $12 \mathrm{t}$. The highest standard deviation of the results is with the vehicles with a carrying capacity up to $3 t, A C V$ and ACG.

It is noteworthy that the results of the DEA and SFA models vary greatly; therefore, decision makers must be aware of that and choose the model in which they want to perform an efficiency assessment.

The results of vehicle efficiency, when calculations were made for vehicles within defined groups (clusters), are given in Table 8.

In small vehicle groups, the SFA models show all vehicles within the group as efficient, and there is certain discrimination only in larger vehicle groups. In this sense, the SFA model will not be commented on in this part of the paper.

The most homogeneous group of vehicles (and the smallest one) consists of the vehicles over $12 t$ capacity - with the average efficiency of 0.92. According to the DEA CCR, the efficient vehicles are those with $\mathrm{mv} 7, \mathrm{mv} 44$ and mv61 markings, and the least efficient is the mv8 vehicle, while the BCC model has 7 efficient vehicles.

In the group of the vehicles up to $12 \mathrm{t}$ of capacity, there are 6 or 10 efficient vehicles according to the DEA models and they are evenly distributed in transport units. 
Table 8 - Average efficiency of vehicles per class

Таблица 8 - Средняя эфрфективность транспортных средств по классам Табела 8 - Просечна ефикасност возила по класама

\begin{tabular}{|l|l|l|l|l|}
\hline $\begin{array}{l}\text { Vehicles up } \\
\text { to 12t } \\
\text { capacity }\end{array}$ & $\begin{array}{l}\text { DEA } \\
\text { CCR }\end{array}$ & $\begin{array}{l}\text { DEA } \\
\text { BCC }\end{array}$ & $\begin{array}{l}\text { SFA } \\
\text { tnorm }\end{array}$ & $\begin{array}{l}\text { SFA } \\
\text { hnorm }\end{array}$ \\
\hline up to 3t & 0.66 & 0.83 & 1.00 & 0.71 \\
\hline up to 6t & 0.60 & 0.65 & 0.86 & 0.74 \\
\hline up to 12t & 0.89 & 0.93 & 1.00 & 1.00 \\
\hline over 12t & 0.92 & 0.96 & 0.99 & 0.99 \\
\hline ACG & 0.62 & 0.77 & 1.00 & 1.00 \\
\hline ACV & 0.80 & 0.91 & 0.91 & 0.91 \\
\hline
\end{tabular}

A group of vehicles with a minimum mean efficiency of 0.60 and 0.65 consists of the vehicles of $3 t$ to $6 t$ capacity, respectively, most of them being in group 78 .

The vehicles with a carrying capacity up to $3 t$ may have unexpectedly low mean efficiency. Six vehicles have an efficiency of less than 0.5 which says they are often used to transport very small loads.

ACGs within the group have 2 or 4 efficient vehicles, and, according to the DEA CCR model, 7 vehicles have efficiency below 0.5. All ACVs have efficiency within a group higher than $50 \%$.

The comparison of the average efficiency of transport units in relation to the vehicle groups was not considered in the work due to the relatively small number of vehicles by defined groups in transport units. In other words, it could not be concluded where and in which transport units certain groups of vehicles are used better.

The comparison of the efficiency of vehicles in general and by defined groups showed that only three vehicles were declared effective in both cases: mv63 to 3t capacity, mv127 ACG and mv152 ACG.

The dependence of data on input and output parameters of transport units and vehicles was tested using the Spearman and Pearson correlation tests. The test results show that the input and output data are independent for all pairs of input and output data except in the case of input data for the vehicles with a capacity of $6 \mathrm{t}$ to $12 \mathrm{t}$.

The results show that the choice of the method of evaluation of technical efficiency has a major impact on the obtained efficiency estimates, and, consequently, on the decisions made and implemented after the efficiency analysis. 


\section{Conclusion}

The paper presents the application of the DEA and SFA methods for evaluating the efficiency of the work of the selected ten military transport units and 173 military motor vehicles used in cargo transportation tasks for the needs of supply and special needs of the army, individually and within six defined classes. It can be deduced from the estimate that the CCR DEA model has the highest discriminatory power that shows the lowest number of efficient units and gives the lowest mean value of efficiency of both transport units and vehicles.

The CCR DEA estimates that three transport units are efficient (with an average efficiency of 0.91), as well as three vehicles (average vehicle efficiency 0.37). The BCC DEA model estimates seven transport units as efficient as well as eight vehicles (average vehicle efficiency 0.46). No transport unit has been declared extremely inefficient (DMU1 has the lowest calculated efficiency with a score of 0.727 per CCR DEA model). Since the carrying capacity of the used vehicles has a large impact on the results of the efficiency of transport units, only one unit with highcapacity vehicles was declared effective, while the least efficient unit has the largest proportion of these vehicles.

With the SFA model, all transport units are rated as efficient. The same is the case with the assessment of the efficiency of vehicles in groups with few vehicles. For this reason, in assessing the efficiency of transport units and military vehicles, the SFA model is applicable in measuring the efficiency of a larger number of DMUs. Of all vehicles, two have the highest efficiency of 0.94 , while the average vehicle efficiency according to the SFA models is 0.74 and 0.8 . Low-capacity vehicles are rated as more efficient according to the DEA models, while the SFA models rate vehicles with higher load capacity as more efficient.

The choice of the method for calculating efficiency can be a determining factor for making management decisions, as it has been shown that the results of the DEA and SFA models differ significantly, about which decision makers must be informed in order to choose the model in which they want to perform efficiency assessment.

The DEA method makes it easier to compare DMUs across multiple inputs or outputs, and for each inefficient unit, it defines respectable units and required changes to the input or output in order to achieve efficiency. The CCR DEA model gives the lowest efficacy results because it allows a constant return to scale and measures the overall technical efficiency and efficiency of the business volume, while the BCC model measures 
only pure technical efficiency, which makes a number of units more efficient.

Since this paper deals with the military context, certain specific information related to the organization, as well as the actual names of transport units, and data on the marks, kind and type of specific vehicles could not be included.

It has been shown that the conducted analysis and efficiency assessment provide a basis for a different approach to the problems of military transport management and more efficient use of vehicles. This paper explores the efficiency of military transport units in a different way than usual. The obtained efficiency results indicate that there is a space for increasing the efficiency of the transport units, especially the efficiency of vehicles. Increased efficiency can be achieved by better vehicle selection in relation to the amount of cargo in order to better utilize the vehicle's capacity. Also, the planning of return transport and better planning of freight transport through reduction of off-plan tasks, with fewer engaged vehicles and, consequently, lower fuel consumption, can increase output, i.e. quantity of transported cargo. By equipping newer vehicles with lower fuel consumption and greater reliability, the input resource needed to complete the tasks can also be reduced.

By choosing an appropriate method for assessing efficiency, input / output parameters and a good analysis of the obtained results, one can obtain a model of transport in the army that would increase the efficiency of transport units and vehicles to a higher level in order to achieve better operational capabilities of the military.

Numerous parameters influence transport efficiency, both at the level of transport units and vehicles. In this sense, the direction of further research on efficiency measurement,would be the influence of the parameters not observed in this paper: type of cargo, vehicle and driver time, organizational structure of the transport unit, distances to which goods are transported, the age of the vehicle, etc. Also, in further work, the influence of the factors on which the organization does not have influence i.e. weather conditions, road conditions, etc, can be investigated.

The work should be the initial phase of the research devoted to the parameters of the efficiency of the military transport units and military vehicles. The efficiency analysis is an important tool that can enable military organization management and transport management to find common solutions in order to achieve the goals of the organization. This would identify proposals for optimizing the use of vehicles for the transport of cargo as well as the engagement of the transport unit as a 
whole, which would increase the quality and quantity of execution of transport tasks in support of the missions and tasks of the Serbian Armed Forces.

\section{References}

Aigner, D., Lovell, C., \& Schmidt, P.1977. Formulation and estimation of stochastic frontier production function models. Journal of Econometrics, 6(1), pp.21-37. Available at: https://doi.org/10.1016/0304-4076(77)90052-5.

Andrejić, M., Bojović, N., \& Kilibarda, M. 2016. A framework for measuring transport efficiency in distribution centers. Transport Policy, 45, pp.99-106. Available at: https://doi.org/10.1016/j.tranpol.2015.09.013.

Andrejić, M., \& Kilibarda, M. 2017. Efikasnost logističkih procesa. Belgrade: Univerzitet u Beogradu - Saobraćajni fakultet (in Serbian).

Banker, R.D., Charnes, A., \& Cooper, W.W. 1984. Some Models for Estimating Technical and Scale Inefficiencies in Data Envelopment Analysis. Management Science, 30(9), pp.1078-1092. Available at: https://doi.org/10.1287/mnsc.30.9.1078.

Banker, R.D., \& Thrall, R.M. 1992. Estimation of returns to scale using data envelopment analysis. European Journal of Operational Research, 62(1), pp.7484. Available at: https://doi.org/10.1016/0377-2217(92)90178-c.

Byrne, P.J., \& Markham, W.J. 1991. Improving Quality and Productivity in the Logistics Process: Achieving Customer Satisfaction Breakthroughts. Council of Logistics Management.

Charnes, A., Cooper, W.W., \& Rhodes, E. 1978. Measuring the efficiency of decision making units. European Journal of Operational Research, 2(6), pp.429-444. Available at: https://doi.org/10.1016/0377-2217(78)90138-8.

Coelli, T., \& Perelman, C. 1996. Efficiency Measurement, Multiple-output Technologies and Distance Functions: With Application to European Railways. In CREPP Working Paper.Liege, Wallonia, Belgium: University of Liege.

Coelli, T., \& Perelman, S. 2000. Technical efficiency of European railways: a distance function approach. Applied Economics, 32(15), pp.1967-1976. Available at: https://doi.org/10.1080/00036840050155896.

Cook, W.D., \& Seiford, L.M. 2009. Data envelopment analysis (DEA) Thirty years on. European Journal of Operational Research, 192(1), pp.1-17. Available at: https://doi.org/10.1016/j.ejor.2008.01.032.

Cooper, W.W., Seiford, L.M., \& Tone, K. 1999. Data Envelopment Analysis: A Comprehensive Text with Models, Applications, References and DEA-Solver Software. Boston: Kluwer Academic Publishers.

Cruijssen, F., Dullaert, W., \& Joro, T. 2010. Freight transportation efficiency through horizontal cooperation in Flanders. International Journal of Logistics Research and Applications, 13(3), pp.161-178. Available at: https://doi.org/10.1080/13675560903224962. 
Dozet, S., Miladinović, V., Jovanović, G., Plaznić, R., Jušković, M., Trifković, M., \& Ostojić, S. 1988. Saobraćajno obezbeđenje oružanih snaga. Belgrade: SSNO, Saobraćajna uprava (in Serbian).

Farrell, M.J. 1957. The Measurement of Productive Efficiency. Journal of the Royal Statistical Society, Series A (General), 120(3), p.253. Available at: https://doi.org/10.2307/2343100.

Gleason, J.M., \& Barnum, D.T. 1982. Toward Valid Measures of Public Sector Productivity: Performance Measures in Urban Transit. Management Science, 28(4), pp.379-386. Available at: https://doi.org/10.1287/mnsc.28.4.379.

Kim, T. 2010. Efficiency of trucks in logistics: technical efficiency and scale efficiency. Asian Journal on Quality, 11(1), pp.89-96. Available at: https://doi.org/10.1108/15982681011051859.

Knežević, N., Bojović, N., \& Kapetanović, M. 2015. Komparativna analiza efikasnosti jedinica poštanske mreže primenom DEA i SFA metoda. In XXXIII Simpozijum o novim tehnologijama u poštanskom i telekomunikacionom saobraćaju - PosTel 2015. Belgrade, pp.9-18. December 01-02 (in Serbian).

Kumbhakar, S.C., \& Knox Lovell, C.A. 2003. Stochastic Frontier Analysis. New York: Cambridge University Press.

Martić, M. 1999. Analiza obavijenih podataka sa primenama. Belgrade: University of Belgrade, The Faculty of Organizational Sciences. Ph.D. thesis (in Serbian).

Meeusen, W., \& van Den, B.J. 1977. Efficiency Estimation from CobbDouglas Production Functions with Composed Error. International Economic Review, 18(2), p.435. Available at: https://doi.org/10.2307/2525757.

Službeni vojni list 2013. Pravilnik o transportu ljudi $i$ sredstava $u$ Ministarstvu odbrane i Vojsci Srbije. Belgrade: Ministarstvo odbrane Republike Srbije (in Serbian).

Softver DEAP Version 2.1. [Internet]. Available at: http://www.uq.edu.au/economics/cepa/deap.php. Accessed: 26.03.2018.

Softver STATA13. [Internet]. Available at: http://www.stata.com. Accessed: 13.02.2018.

Vujaklija, M. 1980. Leksikon stranih reči i izraza. Belgrade: Prosveta, III dopunjeno izdanje (in Serbian).

$\begin{array}{lll}\text { ОЦЕНКА ЭФФЕКТИВНОСТИ ТРАНСПОРТНЫХ } & \text { СРЕДСТВ } \\ \text { ВООРУЖЕННЫХ СИЛ МЕТОДАМИ DЕА И SFА } & \end{array}$

Деян Р. Деспич ${ }^{a}$, Небойша Й. Бојович

Милорад Й. Килибарда ${ }^{б}$, Марко В. Капетановичб

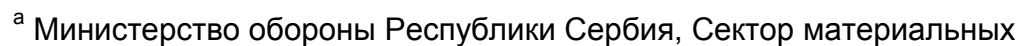
ресурсов, Управление логистикой, г. Белград, Республика Сербия

${ }^{\sigma}$ Белградский университет, Транспортный факультет,

г. Белград, Республика Сербия

ОБЛАСТЬ: математика, логистика, транспорт

ВИД СТАТЬИ: оригинальная научная статья

ЯЗЫК СТАТЬИ: английский 
Резюме:

Целью данной работы являлось проведение анализа эфффективности выбранных транспортных средств и военных боевых машин для осуществления заданий по перевозке груза при применении метода стохастической границы (SFA), а также анализа оболочки данных (DEA), создавая тем самым основание для дальнейших исследований параметров, влияющих на эффрективность работы транспортных средств Вооруженных сил и военных боевых машин. Исследование проведено на основании десяти транспортных средств Вооруженных сил, предназначенных для осуществления логистических задач по транспорту и перевозкам. Анализ эффрективности проведен для военных машин, используемых для выполнения заданий по транспорту и перевозкам груза для нужд снабжения и нужд специального назначения командования, воинских частей $u$ учреждений Вооруженных сил. В работе использованы данные, полученные благодаря программному обеспечению, с помощью которого ведется наблюдение за пользованием и эксплуатацией военных машин в течение одного календарного года. Результаты показали, что выбор метода оказывает большое влияние на полученную оценку технической эфорективности, и соответственно на возможные управленческие решения, принимаемые на основании проведенного анализа эфффективности.

Ключевые слова: эффрективность, транспортные средства Вооруженных сил, военные боевые машины, анализ оболочки данных, метод анализа стохастической границы.

ПРОЦЕНА ЕФИКАСНОСТИ ТРАНСПОРТНИХ ЈЕДИНИЦА ВОЈСКЕ METOДАМА DEA И SFA

Дејан Р. Деспић ${ }^{\mathrm{a}}$, Небојша Ј. Бојовић ${ }^{6}$, Милорад Ј. Килибарда ${ }^{6}$, Марко В. Капетановић ${ }^{б}$

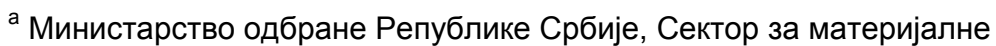

ресурсе, Управа за општу логистику, Београд, Република Србија

б Универзитет у Београду, Саобраћајни факултет,

Београд, Република Србија

ОБЛАСТ: математика, логистика, саобраћај ВРСТА ЧЛАНКА: оригинални научни чланак ЈЕЗИК ЧЛАНКА: енглескИ

\section{Сажетак:}

Циљ рада јесте да се изврши анализа ефикасности изабраних транспортних јединица у логистици Војске и војних возила у реализацији задатака транспорта терета применом метода 
анализе стохастичких граница (SFA) и анализе обавијања података (DEA), као и стварање основе за даље истраживање параметара који утичу на ефикасност рада транспортних јединица Војске и војних возила.

Истраживање је извршено у десет транспортних јединица Војске, намењених за реализацију послова из логистичке функције саобраћај и транспорт. Анализа ефикасности извршена је за војна возила коришћена за реализацију задатака транспорта терета за потребе снабдевања и посебне потребе команди, јединица и установа Војске. Коришћени су подаци добијени из програмског пакета којим се прати коришћење и експлоатација војних моторних возила у периоду од једне календарске године. Резултати показују да избор методе има велики утицај на добијене оцене техничке ефрикасности, а самим тим и на евентулане управљачке одлуке на основу извршене анализе ефрикасности.

Кључне речи: ефикасност, транспортне јединице Војске, војна возила, анализа обавијања података, анализа стохастичких граница.

Paper received on / Дата получения работы / Датум пријема чланка: 04.08.2018. Manuscript corrections submitted on / Дата получения исправленной версии работы / Датум достављања исправки рукописа: 25.09.2018.

Paper accepted for publishing on / Дата окончательного согласования работы / Датум коначног прихватања чланка за објављивање: 27.09.2018.

(c) 2019 The Authors. Published by Vojnotehnički glasnik / Military Technical Courier

(www.vtg.mod.gov.rs, втг.мо.упр.срб). This article is an open access article distributed under the terms and conditions of the Creative Commons Attribution license (http://creativecommons.org/licenses/by/3.0/rs/).

() 2019 Авторы. Опубликовано в «Военно-технический вестник / Vojnotehnički glasnik / Military Technical Courier» (www.vtg.mod.gov.rs, втг.мо.упр.срб). Данная статья в открытом доступе и распространяется в соответствии с лицензией «Creative Commons» (http://creativecommons.org/licenses/by/3.0/rs/)

(c) 2019 Аутори. Објавио Војнотехнички гласник / Vojnotehnički glasnik / Military Technical Courier (www.vtg.mod.gov.rs, втг.мо.упр.срб). Ово је чланак отвореног приступа и дистрибуира се у складу са Creative Commons licencom (http://creativecommons.org/licenses/by/3.0/rs/).

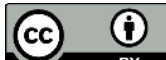

